\title{
Core Values Education of Foreign Students and Its Experience Revelation
}

\author{
Minghui Li \\ College of International Exchange, Bohai University, Jinzhou, 121013, China \\ liminghui0607@sina.cn
}

Keywords: foreign; college students; core values; education; experience revelation

\begin{abstract}
Under the new situation, strengthening the socialist core values education of college students needs a new concept, which is the urgent task faced by colleges and universities. The United States, Britain, Japan and Singapore, although the capitalist countries, in the nature of the country, the social system and the different aspects of China, the core values of the content is not the same, but as the advanced western countries, the concept and method of core values education in college students, and other areas of a lot of good experience, worth learning in china. This paper analyzes the core values of the college students in China, and summarizes the experience revelation, and has important reference value for the cultivation and practice of socialist core values in Chinese college students.
\end{abstract}

\section{Introduction}

College students are the future of the country and the hope of the nation, but also the important power to inherit Chinese excellent traditional culture and realize the great rejuvenation of the Chinese nation. Therefore, it is very important to develop the world outlook, outlook on life and values. With the development of economic globalization, political multi polarization, cultural diversity and information network, and the emergence of many kinds of realistic contradictions in social development, the problem of value education has gradually become the world, the time and the far-reaching. As the important position of the cultivation and practice of the value, the higher education schools must take on the historical mission and the realistic responsibility of the value education. To cultivate the correct world outlook, outlook on life and values, improve the ability of students to distinguish right from wrong and independent thinking, to the healthy growth of college students in favor of to ensure become socialist qualified builders and successors [1]. In many countries, the importance of core values in the promotion of cultural soft power strategy is fully recognized by the cultural diversity, and the core values of education, moral education, civic education, common values education and so on. Analysis and summarize the main practice and experience of the core values education in the advanced countries, and explore the development of the Chinese college students' socialist core values education.

\section{American Core Values Education and Its Experience Revelation}

The core values of the United States in the 6 aspects [2]: "freedom Individual", which is the most important American values, originated in the United States for the pursuit of freedom of religious belief in the United states. At present, has evolved into the pursuit of individual freedom, liberation. In the language of, Americans often love to use "think I... Believe I... Opinion is My...". Even the US Secretary of state, on behalf of the US government, will also use the words of a strong personality, "self-reliance ", which is the necessary psychological quality for Americans to get freedom individual. Americans believe that every life is free, but to really enjoy the freedom must be rely on yourself. This idea is reflected in the language that is when Americans talk, very little by showing off their own family or social relations to raise themselves; "Equality of opportunities", the American ancestors more than the Middle Ages in the middle ages, there is no equal opportunity and noble class. So, in the American continent, the idea of "equality" is written in the constitution. Americans are always willing to listen to others, give others a chance. A man makes mistakes in 
one place, and does not deprive him of his right to be good; "Competition" in other ways, the American people think that competition is eternal, but also a means to prove their position in society, but at the same time, it may have to cooperate with others. Americans understand the competition's victory is not "overweening", but people's understanding and recognition. The Americans also know that the landlord can only explain the past, there will be more challenges, to be optimistic about the challenges; the pursuit of wealth "Seeking the wealth", most of the Americans from the poor, the pursuit of wealth, improve life as the vast majority of immigrants dream. Now that Americans are far more understanding of wealth than their ancestors, time, health, ability, information and so on are beyond the value of the currency itself, money has become a symbol of the Hard work, the majority of Americans will take the Hard work as a means of wealth and wealth. A lot of Americans have taken work as a kind of life. In the face of competition, only to work and keep ahead, to maintain their own in the competition.

Core values are the core of character education, the quality education is the process of guiding and promoting the core value and forming the social needs. The core values of the United States Education around the character education, follow the following 11 principles [3]: a conscious and active and comprehensive approach to promote core values in all areas of school life. In order to provide opportunities for students to use the knowledge. The school must be a caring society. In order to provide students with a conscious, active and comprehensive approach to promote the core values. In order to provide students with a sense of value. Education; schools must absorb all aspects of parents and community members to participate in the quality of training activities; evaluation of the effectiveness of the quality of education, including teachers, administrators and support staff, evaluation content, including the understanding of moral education, beliefs and behavior. The core values education in the United States is to take the school environment construction as an essential way of core values education. The school should provide students with the opportunity to use the core values.

The experience of the United States of America's core values education is to abandon the traditional method of value education, use modern education method, encourage students to think, guide students to discuss and debate controversial issues, help students to learn rational judgment, the use of the method of questioning the teacher, the teacher's authority and role, through compulsory means to make students understand discipline, and consciously abide by discipline. The teacher has the right to ask the students to follow the instruction, observe the discipline, and not do any harm to the individual and the collective interests. But moral authority is not a dictator, teachers should respect and care about the students, pay attention to students' guidance, do a guide, abandon the value neutrality, and clearly define the core values of the students. Emphasizes the core values of the content and the formation of the students' character, emphasizing the core values of the students' identity and in accordance with the core values of action.

\section{British Core Values Education and Its Experience Revelation}

British college students' mainstream values education reflects the common characteristics of the western capitalist culture, namely, freedom, equality, fraternity, rational, democratic, legal, human rights and individualism, etc., but also in the long-term historical development process to form their own unique content, that is, the gentleman culture [4]. Gentleman culture emphasizes that people should have the elegant life temperament, have the higher moral cultivation and polite manner, and pay attention to the pursuit of reason. On the other hand, the value of freedom and personality development, on the other hand, requires people to respect the cultural tradition and the authority of the government, and the emphasis on the performance of social responsibility and work, the value of which is a conservative. In addition, with the intensification of economic globalization process and the value of the infiltration, the mainstream values of the British university education content, reflecting the ideology of capitalist countries and the British national cultural characteristics, but also actively explore and integrate into the fair and justice, innovation, sustainable development, etc.. The value outlook education in the United Kingdom on the value of our country's education experience as follows [5]: 
(1) The important role the core values education in Colleges and universities. British universities pay more attention to their values education, which is reflected in the whole process of higher education, and the value of the unity of the value of the goal oriented, heuristic, osmotic, emotional and other content and form, and continue to deepen the awareness of the elite of social core values and practice.

(2) Pay attention to the function of the traditional culture in the value education. Social core value concept itself is consistent with the national historical cultural psychology, whether to conform to the national spirit of the characteristics, is rooted in the traditional culture, values important content to achieve the efficacy of Human resources. The emphasis on traditional culture is the basis of value view education. The gentleman culture and religious culture, which is formed in the history of British universities, has been implanted into the value of the value of the education, and has become the main body of the value education in Colleges and universities.

(3) Focus on the mainstream values of education in management activities. Management activities are also an educational activity, not only to serve the teaching and scientific research activities in Colleges and universities, but also to play the role of ideological education. British university is very focused on the use of management activities to promote the concept of democracy and the rule of law, not only to attract students to participate in the decision-making process, but also to learn from the legal process of the students complaint, in order to promote the rule of law concept.

(4) The emphasis on the value of education to identify the integration of the deep level role. Social value view is the common and shared values of social members, and ultimately, as the value of the consensus, and the outside for their own initiative. As the British universities have long insisted that the gentleman, gentleman spirit and religious culture, such as the value of the modern capitalist ideology education, both in the hidden and dominant, direct or indirect interaction in the body, is the British Society for the noble type of hard work of the goal pursuit

\section{Japanese Core Values Education and Its Experience Revelation}

In the process of modernization, the value of education, the rapid development of economic and social development to a huge role, this value education from Japan itself, to maintain its own national characteristics, the integration of national power, to promote the national economic and social development, the other is being carried out in the country, has a certain reference value. The biggest characteristic of the new law is to keep the new ideas of respecting the public spirit, developing the rich human nature and inheriting cultural tradition, and establishing the basic value orientation for the development of the education reform in Japan in twenty-first Century, which is based on the theory of "the development of democracy and civilization.". The new basic law set the following five points [6]: first, to grasp the broad knowledge, to develop the pursuit of truth, to cultivate rich moral character and moral character, to develop a healthy physique; second, respect for personal value, develop personality, cultivate innovative spirit, develop independent, self-discipline, pay attention to the close relationship between job and life, pay attention to professional and life attitude; third, pursue justice and responsibility, respect for men and women equality, love, take the public spirit, establish social development contribution to social development, fourth, respect for tradition and culture, love the motherland, respect other countries, is committed to promoting world peace and development. Japan's value education on the value of our experience in education is as follows [7]:

(1) The combination of the value view education highlights the nationality and the times. Japan in the post-war focus on rapid economic and social development, social values education has a distinctive national characteristics and times characteristics, the value of a single nation as the soul of the modern value of the soul can be retained, and the value of education into a distinct era characteristics. The normal national characteristic education combined with the advanced features of the times, has become the motive force of promoting the development of the value concept, adapting to the social progress and the international development. This is the Japanese America was over and after the transformation, and no important reason completely westernized. 
(2) The education of the values of permeability in the conduct of conduct. In the process of economic and social development in the early post-war Japan, the value view of the behavior criterion is very much, and the behavior criterion, especially the details and etiquette of the Japanese people, is a great influence on the development of Japanese youth. The focus is on the guidance of the behavior of the Japanese students, the improvement of the school education, the evaluation of the groups under the background of "shame culture", and the balance of individual freedom and public spirit.

(3) Social development theme integration of value education. The value of the Japanese education service to the country and the social development goal characteristic is very obvious, and in different times showed different characteristics, the value of it is too much to promote the value of the need to be treated with caution. Embodied in: prominent nationalist educational service to capitalism rapid development, implementation freedom and democracy education subject to short democratic national construction, carry forward the "dedication" spirit and enhance the competitiveness of the economy development, promote national self-confidence education to promote the political power.

(4) The state will integrate the values education. Japan from ancient to modern times, both in peacetime and in war, the success of the will of the state into the education of young students, let the common values play a very prominent role in Make the country rich and its military force efficient , economic take-off, the country's modernization. Embodied in: the concept of nationalism into the Meiji period of value view education, democratic thought into the value of the post-war period of the mandate education and corporatism into the value of a period of rapid economic development view of education, " normal state " into society rightist period values education.

\section{Singapore's Core Values Education and Its Experience Revelation}

Core values education as an educational behavior, also need to support the concept and value guidance. On the basis of scientific education law, advanced educational ideas, can provide a lasting internal power for educational practice, and ensure the direction of education. Core values education in Singapore has been adhering to the "harmonious philosophy of education, the education concept and national education philosophy of", as the core value view education escort, make the core value view education achieved significantly superior results [8]. Among them, the "harmonious education concept" is the purpose of education development, for Singapore such a country with a diversity of ethnic, religious and cultural background, the "harmony" is Singapore's founding. Specifically, the core values of education and economic development, the core values of education and social development, "the core values of education and cultural development", "the concept of human oriented education", to create an open and inclusive education system, training students to develop a wide range of development, so that every student to play a director. Cultivate a full range of students, cultivate a confident, active learning and dedication of good citizens. Students choose which road, can ascend their peak; "national education idea" the core values education and national education closely linked together, Singapore's core values education is not the ruling party's political values education, but the social level of national consciousness and national spirit education, focusing on cultivating national identity. Singapore's value education on the value of our experience in education is as follows $[9,10]$ :

(1) With patriotism as the core, the core values of the multi national culture. As a multi-ethnic, multicultural country, in the core values education, we must reflect the cultural differences, respect for the minority culture and social class, the mainstream ideas, values and the idea of minority groups, in the pursuit of value and social value of the community, increase the value of the individual's attention, improve the core value of the system's identity.

(2) In the classroom, the classroom education is the main position, promotes the value view education to enter the classroom. The school education is the main channel of the value, the value of the classroom teaching, not only in the ideological and moral education in the value of education, and in other courses should be integrated and infiltrated, in order to broaden the core values of 
education, so that the core values into every subject areas, so that students can understand the true meaning of the value of different degrees.

(3) Pay attention to the promotion of the legal education to the students' core values. Through the moral education and legal education, make students establish the correct world outlook, outlook on life and values, set up the lofty ideals and beliefs, form a good ideological and moral quality and legal awareness, and become the qualified personnel of modern construction. Through the legal basis of the knowledge of the law, so that college students to form a legal consciousness, to cultivate the law of faith, return to the true, good, the United States and other core values of the formation of.

(4) The use of a variety of forms of communication to promote the value of education and life. Good form of communication to the core values of the system construction can play a multiplier effect. On the one hand, play the advantages of traditional media such as newspapers, magazines, radio, TV and other traditional media, and actively use the Internet, mobile phones and other new channels of communication. On the other hand, to play the advantages of public participation, to carry out "civilized manners", "National Awareness Week" and other national education activities, to promote the common participation of the whole people.

\section{Conclusion}

To strengthen the construction of the socialist core values of college students is not only a realistic requirement of building a harmonious society and realizing the great Chinese dream, but also an effective means of promoting the self education and promoting the comprehensive development of college students [11]. To strengthen the core values education of college students is an urgent task for the ideological and political education in Colleges and universities at present. The United States, Britain, Japan and Singapore, although the capitalist countries, in the nature of the country, the social system and the different aspects of China, the core values of the content is not the same, but as the advanced western countries, the concept and method of core values education in college students, and other areas of a lot of good experience, worth learning in china. In this paper, through in-depth analysis of the core values of the university students of education status, summed up the experience of enlightenment, to carry out the core values of Chinese college students education has an important reference role.

\section{Acknowledgement}

This work is supported by social science fund project of Liaoning province (L15BSZ021): Cultivation Strategy on College Students' Socialist Core Values in Multicultural Perspective

\section{References}

[1] H. P. Huang, "The educational ways of College Students' socialist core values," Education Exploration, vol. 25, no. 5, pp. 105-107, 2015.

[2] Baidu library, "Six core values of the American," http://wenku.baidu.com/link?url=gapPZWQVqkWKXkWVKsToBXcnzpRkoXe3HrLckNCmlt z8sgc1pOuRz7rumIQhs9rMv4BJR9Ra4skmLKP8AiX_y-fMxSeVGFVPN8c3hi9MNpy, 2015-10-3.

[3] S. C. Fan, "The Exploration of Core Value Education in America," Studies in Foreign Education, vol. 35, no. 7, pp. 23-28, 2008.

[4] K. Sun, "The mainstream values education of college students in the UK and Its Enlightenment to China," Beijing Education, vol. 4, no. 11, pp. 78-80, 2011.

[5] X. J. Liu, "Methods and Enlightenments of the value education in British Universities," Socialist Forum, vol. 29, no. 8, pp. 55-56, 2014. 
[6] H. Tian, "School education objective and value education in Japan in twenty-first Century," Moral Education China, vol. 10, no. 11, pp. 57-59, 2010.

[7] N. Hai, J. Li, X. H. Xia, "Analysis of the Japanese Value Education in the Service of its National Development," Journal of University of Shanghai for Science and Technology (Social Sciences Edition), vol. 37, no. 1, pp. 85-89, 2015.

[8] Y. L. Lu, Z. X. Zhang, "Study on the Singapore's Core Values Education Concept," Journal of Nanchang Hangkong University (Social Sciences), vol. 17, no. 1, pp. 114-119, 2015.

[9] J. G. Peng, X. Zhou, "On the Enlightenment of the common values education in Singapore on the cultivation of socialist core values in China," Studies in Ideological Education, vol. 26, no. 8, pp. 47-50, 2014.

[10] S. Y. Liu, "Enlightenment of core values education in Singapore," China Electric Power Education, vol. 25, no. 12, pp. 191-192, 2009.

[11] J. Pan, X. J. Ma, J. C. Zhang, "Realization route of College Students' socialist core values," School party construction and Ideological Education, vol. 33, no. 19, pp. 42-46, 2015. 